\title{
Asupan Energi, Zat Gizi Makro dan Pertambahan Berat Badan Ibu Hamil
}

\section{Energy Intake, Macro Nutrients and Weight Gain for Pregnant Women}

\author{
Nurmela Setia Ningsih ${ }^{1}$, Betty Yosephin Simanjuntak ${ }^{2}$, Miratul Haya ${ }^{3}$ \\ Jurusan Gizi, Politeknik Kesehatan Kemenkes Bengkulu, Indonesia
}

\begin{tabular}{l} 
ARTICLE INFO \\
\hline Article history \\
Received date \\
07 Oct 2020 \\
Revised date \\
06 Apr 2021 \\
Accepted date \\
08 Apr 2021
\end{tabular}

Keywords:

Energy intake;

Macro nutrient;

Pregnant women;

Weight.

\section{Kata kunci:}

Asupan energi;

Zat gizi makro;

Ibu hamil;

Berat badan.

\begin{abstract}
ABSTRAK
Pregnant women are one of the vulnerable groups. During pregnancy, there is an increase in the need for nutrients to meet the needs of the mother and fetus as well as preparation for labor. It is very important to pay attention to the recommended weight gain during pregnancy to prevent the occurrence of low birth weight. The purpose of this study was to determine the relationship between energy, carbohydrate, fat, and protein intake on weight gain of pregnant women in the city of Bengkulu. The design of this study was a crosssectional study with a total sample of 47 pregnant women who had received an education of the first thousand days of life when registering to become a prospective bride at the Religious Affairs Office. As many as $53.2 \%$ of mothers had good weight gain and had a relationship between energy intake ( $\mathrm{p}$-value 0,032 ), carbohydrate intake ( $\mathrm{p}$-value 0,024$)$, protein intake (p-value 0,039), and fat intake (p-value 0,023). Energy and macronutrients have a relationship with the weight gain of pregnant women in the group of preconception couples who have received education about the first 1000 days of life. It is hoped that pregnant women will be able to control their weight during pregnancy and apply the knowledge that has been obtained through education while preconception age.
\end{abstract}

Ibu hamil adalah salah satu kelompok rawan gizi. Selama kehamilan terjadi peningkatan kebutuhan zat gizi untuk memenuhi kebutuhan ibu dan janinnya serta persiapan persalinan. Pertambahan berat badan yang sesuai anjuran selama kehamilan sangat penting diperhatikan untuk mencegah terjadinya berat badan lahir rendah (BBLR). Tujuan penelitian ini adalah untuk mengetahui hubungan antara asupan energi, karbohidrat, lemak, dan protein terhadap pertambahan berat badan ibu hamil di kota Bengkulu. Desain penelitian ini adalah potong lintang dengan jumlah sampel 47 ibu hamil yang telah mendapatkan edukasi 1000 HPK ketika mendaftar menjadi calon pengantin di KUA. Sebanyak 53,2\% ibu memiliki pertambahan berat badan baik, dan memiliki hubungan antara asupan energi ( $p$-value 0,032$)$, asupan karbohidrat ( $p$-value 0,024$)$, asupan protein ( $p$-value 0,039$)$ dan asupan lemak $(p$-value 0,023$)$. Energi dan zat gizi makro memiliki hubungan dengan pertambahan berat badan ibu hamil pada kelompok pasangan catin yang telah mendapatkan edukasi 1000 HPK. Diharapkan kepada ibu hamil untuk dapat melakukan pengontrolan berat badan selama kehamilan dan dan menerapkan pengetahuan yang telah diperoleh melalui edukasi saat calon pengantin.

Corresponding Author:

Betty Yosephin Simanjuntak

Jurusan Gizi, Politeknik Kesehatan Kemenkes Bengkulu, Indonesia

Email: patricknmom@yahoo.co.id

\section{PENDAHULUAN}

Salah satu kelompok rawan gizi adalah ibu hamil. Kebutuhan gizi semakin meningkat seiring bertambahnya usia kehamilan. Hal ini terjadi dalam rangka pemenuhan kebutuhan zat gizi untuk memenuhi kebutuhan ibu dan janin yang meningkat. Kekurangan gizi pada ibu hamil berdampak pada ibu dan perkembangan janinnya, antara lain kematian ibu, abortus, bayi lahir dengan berat badan rendah. Beberapa penelitian membuktikan bahwa untuk memperbaiki suatu hasil/outcome kehamilan, misalnya berat badan lahir, intervensi melalui perbaikan status gizi sebaiknya dimulai sebelum kehamilan, termasuk meningkatkan asupan mikronutrien dan 
meningkatkan berat badan sebelum kehamilan (Hambidge, et al., 2016).

Masalah gizi menjadi penyebab kematian ibu dan anak yang sebenarnya masih dapat dicegah. Asupan gizi kurang dan status gizi ibu hamil dapat menimbulkan berbagai dampak bagi ibu dan janin. Salah satunya bayi lahir dengan berat lahir rendah (Kementerian Kesehatan RI, 2014). Oleh karena itu, ibu dengan kondisi tidak tercukupi aupan selama minggu terakhir kehamilan akan melahirkan bayi dengan berat badan rendah $(<2500 \mathrm{~g})$, karena jaringan lemak banyak ditimbun selama trimester III (Fitri \& Wiji, 2018).

Asupan makanan ketika hamil berbeda dengan asupan sebelum kehamilan (Koletzko, et al., 2019). Berdasarkan angka kecukupan gizi (AKG) tahun 2019 ditambahkan energi sebesar 180 kkal perhari selama kehamilan trimester satu, protein 1g/hari, lemak 2,3g/hari, dan karbohidrat $25 \mathrm{~g} /$ hari. Sementara pada trimeter dua terjadi penambahan energi 300kkal, protein $10 \mathrm{~g} / \mathrm{hari}$, lemak 2,3g/hari, dan karbohidrat 40g/hari dan pada trimester tiga ditambahkan energi $300 \mathrm{kkal}$, protein 30g/hari, lemak 2,3g/hari, karbohidrat 40g/hari (Kementerian Kesehatan RI, 2019).

Kenaikan berat badan ibu selama hamil dapat digunakan sebagai indikator untuk menentukan status gizi ibu hamil, karena terdapat persamaan dalam rata rata kenaikan berat badan saat hamil pada semua ibu hamil (Setyarahma, 2019). Rata-rata total pertambahan berat badan ibu hamil berkisar $10-15 \mathrm{~kg}$ yaitu $1 \mathrm{~kg}$ pada trimester I dan selebihnya pada trimester II dan III (Fitriana, 2017). Mulai trimester II sampai III rata-rata pertambahan berat badan adalah 0,3$0,7 \mathrm{~kg} / \mathrm{minggu}$ atau $3,6-8,4 \mathrm{~kg} /$ trimester II dan III, Penambahan berat badan yang diharapkan pada kehamilan trimester I adalah 2-4 $\mathrm{kg}$, pada trimester II $0,4 \mathrm{~kg}$ per minggu atau $5,6 \mathrm{~kg}$ pada trimester II, dan trimester III $0,5 \mathrm{~kg}$ atau kurang per minggu atau $7 \mathrm{~kg}$ pada trimester III (Shiddiq, Lipoeto, \& Yusrawati, 2015).

Penambahan berat badan yang sesuai anjuran selama kehamilan sangat penting diperhatikan untuk mencegah terjadinya Berat Badan Lahir Rendah (BBLR) dimana angkanya cukup besar di Jawa Timur yaitu 11\% (Fitriana, 2017). Hal ini berarti bahwa asupan makanan ibu hamil (terutama energi, protein, karbohidrat, dan lemak) berpengaruh terhadap penambahan berat badan ibu hamil. Namun beberapa penelitian pertambahan ibu hamil tidak mengalami kenaikan berat badan sesuai usia kehamilannya (Yongky, Hardinsyah, Gulardi, \& Marhamah, 2009).
Penelitian sebelumnya oleh Simanjuntak di tahun 2019 telah dilakukan yakni memberikan edukasi kepada calon pengantin di KUA, namun belum dilakukan penelitian lanjutan terhadap asupan energi, zat gizi makro (karbohidrat, protein, lemak) dan pertambahan berat badan setelah mendapatkan edukasi (Simanjuntak, 2021). Oleh karena itu penelitian ini bertujuan untuk menilai hubungan antara asupan energi, karbohidrat, lemak, dan protein terhadap pertambahan berat badan ibu hamil yang telah mendapatkan edukasi 1000 HPK pada saat calon pengantin di KUA Kota Bengkulu.

\section{METODE}

Penelitian ini telah mendapatkan persetujuan dari Komisi Etik Penelitian No.245/V/2019 Komisi Bioetik Fakultas Kedokteran Universitas Islam Sultan Agung Semarang. Penelitian ini merupakan penelitian analitik yang menggunakan desain Cross Sectional. Populasi penelitian adalah ibu hamil sebanyak 120 orang yang sudah mendapatkan edukasi 1000 HPK saat menjadi calon pengantin di KUA kota Bengkulu. Untuk menghitung besar sampel digunakan rumus Lemeshow, diperoleh sebanyak $47 \mathrm{ibu}$ hamil, menggunakan teknik purposive sampling.

Asupan energi yang tidak baik dengan kode 0 jika asupan $<100 \%$ AKG atau $>105$ AKG untuk asupan energi yang baik dengan kode 1 jika asupan 100-105\% AKG, asupan karbohidrat yang tidak baik dengan kode 0 jika asupan $<80 \%$ AKG atau $>100 \%$ AKG untuk asupan karbohidrat yang baik dengan kode 1 jika asupan 80-100\% AKG, asupan lemak yang tidak baik dengan kode 0 jika asupan $<80 \%$ AKG atau $>100 \%$ AKG untuk asupan lemak yang baik dengan kode 1 jika asupan 80-100\% AKG. Asupan protein yang tidak baik dengan kode 0 jika asupan $<80 \%$ AKG atau $>100 \%$ AKG untuk asupan protein yang baik dengan kode 1 jika asupan $80-100 \%$ AKG.

Pertambahan berat badan ibu hamil berbeda di setiap trimester kehamilan, dikumpulkan dengan menanyakan berat badan sebelum hamil dan berat badan saat. Selisih antara berat badan saat ini dan berat badan sebelum hamil disebut pertambahan berat badan . Kategori pertambahan berat badan ibu hamil baik jika $\geq 2-4 \mathrm{~kg}$ pada trimester $1, \geq 5,6 \mathrm{~kg}$ atau $0,4 /$ minggu pada trimester $2, \geq 0,5 \mathrm{~kg}$ atau $7 \mathrm{~kg}$ pada trimester III (Shiddiq, et al., 2015). Analisis data menggunakan uji Chi-Square. 
HASIL Tabel 1. Deskripsi Asupan Zat Gizi, hamil $28(59,6 \%)$ memiliki asupan energi baik, Pertambahan Berat Badan Ibu $26(55,3 \%)$ memiliki asupan karbohidrat tidak Hamil, Usia, dan Usia Kehamilan

\begin{tabular}{lcc}
\hline \multicolumn{1}{c}{ Variabel } & n & \% \\
\hline Asupan Energi & & \\
Tidak Baik & 19 & 40,4 \\
Baik & 28 & 59,6 \\
Asupan Karbohidrat & & \\
Tidak Baik & 26 & 55,3 \\
Baik & 21 & 44,7 \\
Asupan Lemak & & \\
Tidak Baik & 41 & 87,2 \\
Baik & 6 & 12,8 \\
AsupanProtein & & \\
Tidak Baik & 26 & 55,3 \\
Baik & 21 & 44,7 \\
Pertambahan Berat Badan Ibu Hamil & \\
Tidak Baik & 22 & 46,8 \\
Baik & 25 & 53,2 \\
Usia Ibu & & \\
<20 tahun & 1 & 2,1 \\
20-35 tahun & 46 & 97,9 \\
Usia Kehamilan & & \\
Trimester 1 & 16 & 34,0 \\
Trimester 2 & 19 & 40,5 \\
Trimester 3 & 12 & 25,5 \\
\hline
\end{tabular}

Tabel 2. Hubungan Asupan Zat Gizi dengan Pertambahan Berat Badan Ibu Hamil

\begin{tabular}{|c|c|c|c|c|c|c|c|c|c|}
\hline \multirow{3}{*}{ Variabel } & \multirow{3}{*}{ Kategori } & \multicolumn{2}{|c|}{$\begin{array}{c}\text { Pertambahan } \\
\text { Berat Badan }\end{array}$} & \multirow{3}{*}{$\mathbf{n}$} & \multirow{3}{*}{$\%$} & \multirow{3}{*}{$\mathbf{n}$} & \multirow{3}{*}{$\%$} & \multirow{3}{*}{ p-value } & \multirow{3}{*}{ OR } \\
\hline & & $\begin{array}{l}\text { Tidak } \\
\text { Baik }\end{array}$ & Baik & & & & & & \\
\hline & & n & $\%$ & & & & & & \\
\hline \multirow{2}{*}{ Asupan Energi } & Tidak Baik & 13 & 68,4 & 6 & 31,6 & 19 & 100 & 0,032 & 4,615 \\
\hline & Baik & 9 & 32,1 & 19 & 67,9 & 28 & 100 & & \\
\hline \multirow{2}{*}{ Asupan Karbohidrat } & Tidak Baik & 16 & 61,5 & 10 & 38,5 & 26 & 100 & 0,024 & 5,071 \\
\hline & Baik & 6 & 28,6 & 15 & 71,4 & 21 & 100 & & \\
\hline \multirow{2}{*}{ Asupan Lemak } & Tidak Baik & 22 & 53,7 & 19 & 46,3 & 41 & 100 & 0.023 & 6,053 \\
\hline & Baik & 1 & 16,7 & 5 & 83,3 & 6 & 100 & & \\
\hline \multirow{2}{*}{ Asupan Protein } & Tidak Baik & 16 & 61,5 & 10 & 38,5 & 26 & 100 & 0,039 & 3,833 \\
\hline & Baik & 6 & 28,6 & 15 & 71,4 & 21 & 100 & & \\
\hline
\end{tabular}

Berdasarkan tabel 2 diketahui bahwa dari $47(68,4 \%)$ ibu hamil, memiliki asupan energi tidak baik dengan pertambahan berat badan tidak baik, diperoleh nilai $p$-value $=0,032$, maka dapat disimpulkan bahwa ada hubungan yang bermakna antara asupan energi dengan pertambahan berat badan pada ibu hamil. Selanjutnya ada hubungan yang bermakna antara asupan karbohidrat, lemak dan protein dengan pertambahan berat badan pada ibu hamil di Kota Bengkulu, masing masing nilai $p$-value adalah $0.024,0,023$ dan 0,039 . baik, $41(87,23 \%)$ memiliki asupan lemak tidak baik, $26(55,3 \%)$ memiliki asupan protein tidak baik, dan $25(53,2 \%)$ memiliki pertambahan berat badan nya baik. Sementara untuk data usia ibu mayoritas di usia yang paling sesuai untuk hamil yaitu berusia 20-35 tahun. Usia kehamilan sebesar $40,5 \%$ berada pada usia kehamilan trimester 2 ( $4-6$ bulan).

\section{PEMBAHASAN}

Responden penelitian ini adalah ibu hamil dan merupakan kehamilan pertama yang telah mendapatkan edukasi 1000 HPK. Pertambahan berat badan selama hamil sangat penting untuk menentukan kesehatan janin dan status gizi bayi yang akan dilahirkan, kemudian dampak negatif apabila pertambahan berat badan yang tidak sesuai selama kehamilan berakibat pada ibu maupun bayinya.

Kementerian kesehatan merekomendasi kenaikan berat badan saat hamil yaitu $5-12 \mathrm{~kg}$. Kenaikan yang berlebih dapat mengakibatkan proses kelahiran secara caesar, asfiksia 
(gangguan paru) dan diabetes gestational. Di sisi lain, menurut Fajrina (2011) ibu dengan kenaikan BB yang kurang maka risiko melahirkan bayi dengan berat lahir rendah lebih tinggi (Fajrina, 2011; IOM, 1990, dalam Triwijayanti, 2012).

Asupan energi ibu hamil sebagian besar dikatagorikan baik yaitu asupan memenuhi AKG. AKG menganjurkan energi 2250Kkal/hari ditambah 180-300Kkal/hari selama kehamilan. Penambahan ini diperlukan untuk memenuhi kebutuhan ibu hamil dan perkembangan janinnya (Kementerian Kesehatan RI, 2019).

Hasil penelitian ini sejalan dengan penelitian Haryani, et al., (2013) menyebutkan ada hubungan yang signifikan antara tingkat konsumsi energi, tingkat konsumsi protein, dan frekuensi periksa kehamilan dengan pertambahan berat badan ibu hamil trimester II. Berdasarkan uji statistik yang dilakukan didapatkan p-value 0,032 . Hal ini menunjukkan bahwa terdapat hubungan yang signifikan antara asupan energi dengan pertambahan berat badan pada ibu hamil. Penelitian ini sejalan dengan Setyarahma, et al (2019) didapatkan adanya hubungan yang signifikan antara asupan energi $(p$-value $<0,00)$ dengan pertambahan berat badan ibu hamil. Konsumsi gizi yang cukup serta diiringi latihan fisik yang ringan sehingga akan memberi dampak baik bagi ibu hamil. Adanya aktifitas fisik yang cukup akan sangat membantu meningkatkan tingkat kecukupan energi responden (Adam, 2013).

Menurut penelitian Fitriana (2017) penambahan berat badan yang sesuai anjuran selama kehamilan sangat penting diperhatikan untuk mencegah terjadinya Berat Badan Lahir Rendah (BBLR) dimana angkanya cukup besar di Jawa Timur yaitu $11 \%$ hal ini berarti bahwa asupan makanan ibu hamil (terutama energi, protein, karbohidrat, dan lemak) berpengaruh terhadap penambahan berat badan ibu hamil (Fitriana, 2017).

Sumber karbohidrat yang sering dikonsumsi oleh ibu hamil pada penelitian ini adalah nasi putih, roti, makanan yang mengandung karbohidrat lain seperti kue manis lainnya. Asupan energi pada ibu hamil didapatkan bahwa 28 ibu hamil $(59,6 \%)$ memiliki asupan energi kategori baik (mencapai 100$105 \%$ dari $\mathrm{AKG})$. Angka kecukupan gizi energi untuk wanita usia 19-29 tahun yaitu sebesar $2250 \mathrm{Kkal} / \mathrm{hari}$ dan ditambahkan energi per trimester yaitu $180 \mathrm{Kkal}$ pada trimester satu, $300 K k a l$ pada trimester dua dan tiga.

Hasil uji statistik didapatkan.hubungan yang signifikan antara asupan karbohidrat dengan pertambahan berat badan ibu hamil ( $p$-value
0,024). Hal ini sejalan dengan penelitian Fitri \& Wiji (2018) menunjukkan bahwa asupan zat gizi makro yaitu karbohidrat berpengaruh signifikan terhadap berat lahir bayi ( $p$-value $<0,05)$. Demikian juga dengan kenaikan berat badan selama hamil dipengaruhi asupan karbohidrat. Asupan karbohidrat harian yang kurang berpeluang tiga kali lebih besar kemungkinan melahirkan bayi BBLR dibanding ibu dengan asupan karbohidrat baik (Bianchi, Mariotti, Verger, \& Huneau, 2016). Karbohidrat berperan penting dalam pembesaran sel pada proses hipertrofi yang akan mempengaruhi pertambahan berat badan bayi, terutama pada trimester tiga kehamilan dan juga karbohidrat dapat memenuhi hampir $60 \%$ energi yang dibutuhkan oleh ibu hamil. Jika asupan karbohidrat mampu memenuhi kebutuhan energi, maka akan membantu dalam pembentukan plasenta, pertumbuhan janin, pembuluh darah, persediaan lemak, serta perubahan metabolisme tubuh (Shiell, et al., 2001).

Ada hubungan yang signifikan antara tingkat konsumsi energi dengan pertambahan berat badan pada ibu hamil (Haryani, et al., 2013). Ketidakseimbangan asupan energi menunjukkan konsep gizi seimbang belum terimplementasi dengan baik (Borge, Aase, Brantsæter, \& Biele, 2017).

Asupan karbohidrat pada ibu hamil didapatkan bahwa 26 ibu hamil $(55,3 \%)$ memiliki asupan karbohidrat tidak baik 19 diantara nya memiliki nilai dibawah AKG dan 7 diatas AKG, gambaran asupan karbohidrat dikatakan tidak baik karena belum mencapai $80-100 \%$ dari AKG. Angka kecukupan gizi karbohidrat usia 19-29 tahun yaitu sebesar 360g/hari dan ditambahkan karbohidrat per trimester yaitu $25 \mathrm{~g}$ pada trimester satu, 40g pada trimester dua dan tiga.

Penelitian ini tidak sejalan dengan penelitian yang dilakukan Triwijayanti (2012) menunjukkan tidak ada hubungan yang bermakan antara asupan karbohidrat dengan kenaikan BB hamil. Sama halnya dengan penelitian Fitriana (2017) yang menyatakan bahwa tidak ada hubungan antara asupan karbohidrat terhadap peningkatan berat badan pada ibu hamil.

Asupan protein pada ibu hamil didapatkan bahwa 26 ibu hamil $(55,3 \%)$ memiliki asupan protein tidak baik 15 (memiliki nilai di bawah AKG) dan 11 di atas AKG. Gambaran asupan protein dikategorikan tidak baik (belum mencapai 80-100\% dari AKG). Angka kecukupan gizi protein untuk wanita usia 19-29 tahun yaitu sebesar $60 \mathrm{~g} / \mathrm{hari}$ dan ditambahkan protein per trimester yaitu $1 \mathrm{~g}$ pada trimester satu, $10 \mathrm{~g}$ pada trimester dua, dan $30 \mathrm{~g}$ pada trimester tiga. 
Setyarahma, et al. (2019) melaporkan bahwa ada hubungan antara asupan protein dengan pertambahan berat badan ibu hamil. Berdasarkan hasil food recall sebagian besar ibu hamil dalam penelitian ini menyatakan bahwa makanan yang sering dikonsumsi sebagai sumber protein seperti tahu, tempe, telur, dan ikan. Namun masih terdapat ibu hamil variasi makanan sumber protein yang mereka konsumsi sehari-hari masih kurang bervariasi. Protein Fungsi protein selama kehamilan untuk pertumbuhan dan perkembangan janin, plasenta, uterus, payudara untuk persiapan menyusui serta peningkatan volume darah ibu (Setyarahma, et al., 2019).

Peningkatan kebutuhan protein pada ibu hamil meningkat terutama pada trimester II dan III. Hampir $70 \%$ protein dalam tubuh ibu hamil digunakan untuk membentuk jaringan baru dan pertumbuhan janin yang sangat cepat. Konsekuensi dari kekurangan protein pada ibu hamil secara signifikan berdampak pada panjang dan berat bayi lahir. Konsekuensi bila asupan protein yang rendah juga akan berpengaruh terhadap total asupan energi pada ibu hamil dan berpengaruh signifikan terhadap berat lahir bayi (Fitri \& Wiji, 2018). Bahan makan sebagai sumber protein diperoleh ibu hamil dari tahu, tempe, telur, dan ikan laut.

Hasil penelitian ini memperlihatkan ada hubungan antara asupan lemak dan protein dan pertambahan berat badan ibu hamil. Asupan lemak pada ibu hamil didapatkan bahwa 41 ibu hamil $(87,2 \%)$ memiliki asupan lemak tidak. AKG lemak untuk wanita usia 19-29 tahun yaitu sebesar $65 \mathrm{~g} /$ hari dan ditambahkan lemak per trimester yaitu 2,3g pada trimester satu, dua dan tiga. Penelitian Setyarahma, et al. (2016), yang menyimpulkan bahwa semakin terpenuhinya asupan lemak maka semakin tinggi pertambahan berat badan ibu hamil. Fungsi lemak dalam masa kehamilan sebagai sumber energi, sumber asam lemak esensial, memelihara suhu tubuh dan sebagai pelindung plasenta, sebagai persiapan produksi ASI (Setyarahma, et al., 2019).

\section{DAFTAR PUSTAKA}

Adam, N. (2013). Hubungan Tingkat Pendidikan dan Pengetahuan dengan Kekurangan Energi Kronik (KEK) Pada Ibu Hamil di Puskesmas Ampana Timur Kecamatan Ampanan Kota. [Skripsi]. Palu: Universitas Muhammadiyah Palu.
Penelitian lain yang mendukung Fitri \& Wiji, (2018) menunjukkan bahwa asupan lemak berpengaruh signifikan terhadap berat lahir bayi (Fitri \& Wiji, 2018). Proporsi lemak tergolong baik sekitar 20-30\% dari total energi namun pada ibu dengan IMT lebih tinggi, harus memperhatikan asupan lemak karena ibu pada kategori ini cenderung mendapatkan energi dari lemak simpanan dalam tubuh dan umumnya tidak memiliki kenaikan berat badan yang berlebih (Danielewicz, Myszczyszyn, D, Myszkal, \& Bozna, 2017).

Lemak akan diangkut menuju hati untuk disebarkan ke seluruh tubuh, terutama pada kondisi ibu hamil dengan peningkatan metabolisme tubuh untuk memenuhi kebutuhan ibu dan janin (Hartriyanti, Suyoto, Muhammad, \& Palupi, 2012). Bayi dengan BBLR kemungkinan juga disebabkan oleh ketidakseimbangan hormonal atau penyerapan tubuh ibu yang kurang baik ketika hamil sehingga transfer lemak ke janin tidak sempurna dan kebutuhan bayi akan lemak tidak tercukupi (Dieny, Jauharany, Fitranti, Tsani, \& Rahadiyanti, 2019). Hasil food recall ibu hamil memperlihatkan bahan makanan yang sering dikonsumsi mengandung banyak lemak seperti goreng-gorengan, tahu goreng dan tempe goreng serta responden banyak mengonsumsi bahan makanan yang mengandung banyak garam seperti mie instan dan kecap.

\section{SIMPULAN}

Energi dan zat gizi makro memiliki hubungan dengan pertambahan berat badan ibu hamil pada kelompok pasangan catin yang telah mendapatkan edukasi 1000 HPK. Diharapkan kepada ibu hamil untuk dapat melakukan pengontrolan berat badan selama kehamilan dan menerapkan pengetahuan yang telah diperoleh melalui edukasi saat catin di KUA kota Bengkulu.

Bianchi, C. M., Mariotti, F., Verger, E. O., \& Huneau, J. F. (2016). Pregnancy requires major changes in the quality of the diet for nutritional adequacy: simulations in the French and the United States populations. PloS one, 11(3), e0149858. 
Borge, T. C., Aase, H., Brantsæter, A. L., \& Biele, G. (2017). The importance of maternal diet quality during pregnancy on cognitive and behavioural outcomes in children: a systematic review and meta-analysis. $B M J$, 7, 1-14. https://doi.org/10.1136/bmjopen2017-016777

Danielewicz, H., Myszczyszyn, G., D, A., Myszkal, A., \& Bozna, A. (2017). Diet in pregnancy-more than food. 1573-1579. https://doi.org/10.1007/s00431-017-3026-5

Dieny, F. F., Jauharany, F. F., Fitranti, D. Y., Tsani, A. F. A., \& Rahadiyanti, A. (2019). Kualitas diet , kurang energi kronis (KEK), dan anemia pada pengantin wanita di Kabupaten Semarang. Jurnal Gizi Indonesia, 8(1), 1-10.

Fitri, I., \& Wiji, R. N. (2018). Asupan zat gizi makro dan kenaikan berat badan selama hamil terhadap luaran kehamilan. Jurnal Gizi Klinik Indonesia, 15(2), 66. https://doi.org/10.22146/ijen.39163

Fitriana, N. (2017). Hubungan Asupan Energi, Protein, Karbohidrat, dan Lemak Terhadapt Peningkatan Berat Badan Ibu Hamil Trimester 1 dan Trimester 2 Di Wilayah Kota Malang. [Tesis]. Malang: Universitas Brawijaya.

Hambidge, K. M. Krebs, N. F. Westcott, J. E. Garces, A. Goudar, S. S. Kodkany, B. S. Pasha, O. Tshefu, A. Bose, C. L. Figueroa, L. Goldenberg, R. L. Derman, R. J. Friedman, J. E. Frank, D. N. McClure, E. M. Stolka, K. Das, A. Koso-Thomas, M. Sundberg, S. (2016). Preconception maternal nutrition: A multi-site randomized controlled trial. World Review of Nutrition and Dietetics, 114, 136-137. https://doi.org/10.1159/000441824

Hartriyanti, Y., Suyoto, P. S., Muhammad, H. F., \& Palupi, I. R. (2012). Nutrient intake of pregnant women in Indonesia: a review. Malaysian journal of nutrition, 18(1).

Haryani, F. D., Ss, D., \& Rakhmawatie, M. D. (2013). Hubungan Karakteristik, Tingkat Konsumsi Energi, Tingkat Konsumsi Protein, dan Frekuensi Periksa Kehamilan dengan Pertambahan Berat Badan Ibu Hamil Trimester II. Jurnal Kedokteran Muhammadiyah,1(2),32-41.

https://jurnal.unimus.ac.id/index.php/kedokte $\mathrm{ran} /$ article/download/1345/1400
Kementerian Kesehatan RI. (2014). Pedoman Gizi Seimbang. Jakarta: Direktorat Jendral Bina Gizi dan KIA.

Kementerian Kesehatan RI. (2019). Angka Kecukupan Gizi 2019 (Vol. 8). Jakarta.

Koletzko, B., Godfrey, K. M., Poston, L., Szajewska, H., Van Goudoever, J. B., De Waard, M., ... Zalewski, B. M. (2019). Nutrition during pregnancy, lactation and early childhood and its implications for maternal and long-term child health: The early nutrition project recommendations. Annals of Nutrition and Metabolism, 74(2), 93-106. https://doi.org/10.1159/000496471

Setyarahma, A. F. . M. I. K. R. A. (2019). Hubungan Asupan Makanan Dengan Penambahan Berat Badan Pada Remaja Hamil Usia 15-19 Tahun (Studi pada Kelurahan Rowosari Kota Semarang). Jurnal Kesehatan Masyarakat (E-, 53(9), 1689-1699.

Simanjuntak, B. Y., \& Wahyudi, A. (2021). Edukasi tentang 1000 hari pertama kehidupan dalam meningkatkan pengetahuan dan sikap calon pengantin laki-laki.AcTion: Aceh Nutrition Journal, 6(1), 100-110.

Shiddiq, A., Lipoeto, N. I., \& Yusrawati, Y. (2015). Hubungan Pertambahan Berat Badan Ibu Hamil terhadap Berat Bayi Lahir di Kota Pariaman. Jurnal Kesehatan Andalas, $\quad 4(2), \quad$ 472-477. https://doi.org/10.25077/jka.v4i2.276

Shiell, A. W., Campbell-brown, M., Haselden, S., Robinson, S., Godfrey, K. M., \& Barker, D. J. P. (2001). High-Meat, LowCarbohydrate Diet in Pregnancy. 12821288.

Triwijayanti, P. (2012). Asupan Maknan, IMT dan Kenaikan Berat Badan Hamil Di Kelurahan Tanah Baru Kota Bogor Tahun 2012 Hamil Di Kelurahan Tanah Baru Kota Bogor Tahun 2012. [Skripsi]. Bogor: Universitas Indonesia.

Yongky, Y., Hardinsyah, H., Gulardi, G., \& Marhamah, M. (2009). Status Gizi Awal Kehamilan Dan Pertambahan Berat Badan Ibu Hamil Kaitannya Dengan BBLR. Jurnal Gizi Dan Pangan, 4(1), 8. https://doi.org/10.25182/jgp.2009.4.1.8-12 